Commun. Fac. Sci. Univ. Ank. Ser. C

V. 6 , pp 29-45 (1988)

\title{
A PHYTOSOCIOLOGICAL RESEARCH ON THE SYLVATIC VEGETATION OF ÇANKIRI, ÇORUM ANI SUNGURLU
}

\author{
MUSTAFA AYDOĞDU \\ Departmeni of Biology-Faculty of Science-University of Ankara, T'urkey
}

\section{SUMMARY}

This study was carried out on the sylvatic vegetation in the north-east part of the peripheral zone of the Central Anatolia. The vegetation which is under the effective control of a semi arid-very cold type of Mediterranean climate was analyzed by the three dimensional ordinaticn technique based on the BRAUN-BLANQUET approach. The associations described in the area were included in the class Quercetea ilicis of Mediterranean origin and in the alliance Quercion anatolicae of the class Quercetea pubescentis regarding their ecologic and floristic pecularities.

\section{INTRODUCTION}

The study area is situated in the north-east of the Central Anatolia, Çankirı in the west, Corum in the east and Sungurlu in the south.

The previous works done on the vegetation of Turkey covers particularly the northern and southern parts of Anatolia. Much less attention has been paid to the vegetation of the ecotones between the main geographical region in Anatolia even though they exhibites on interesting structure in respect to flora, plant ecology and phytosociology.

The aim of the study is to determine the syntaxonomical units in such area like that and their relationships with the environment.

In the present work, the phytosociological structure of the plant groups in the area was described for the first time.

The geographycal and climatical conditions of the area have entailed to form three different plant groups.

It is believed that this study will supply a complementary information to the floristic and vegetational researches carrying out in Turkey. 


\section{MATERIAL and METHODS}

The study was carried out in two years, between the periods of early spring 1984 and autumn 1986. The specimens of the plants were collected and the quadrats which belongs to plant communities were done during the study.

In the course of the study, the vegetation of the area was tried to be described hy means of the quadrats laid in the area with a homogeneous plant cover.

A great number of plant specimens collected in the study area were identifed by the authors in the herbarium of the biology department of the Science Faculty of Ankara and some were sent to the other herbaria.

The geological data were obtained from the reports of the M.T.A. institute. The climatic characteristics were estimated depending on the data of the meteorological bulletins of State Meteorological Service of Turkey.

The soil specimens which belong to plant groups were taken during the study and then were analyzed in the laboratory of the biology department of Science Faculty of Ankara, using the following methods;

Texture: With hydrometer method of Bouyoucos

Gypseous: With acetone method

Lime $\%$ and $\mathrm{CaCO} 3 \%$ : With titration

$\mathrm{pH}$ : With $\mathrm{pH}$ meter

Conductance: With Conductance Bridge instrument

The solved Cations within the water:

$\mathrm{Mg}$ and $\mathrm{Ca}$ : With titration

$\mathrm{Na}$ and $\mathrm{K}$ : With the Flame photometric method.

The quadrats were classified by the polar ordination methods (Bray and Curtis, 1953) based on Braun-Blanquet approach in order to form the syntaxonomical units in the area.

\section{BRIEF DESCRIPTION OF THE STUDY AREA (Map: 1)}

The study area situated in the north-east of the central Anatolia is generally covered with the calcerous soils. While the altitudinal 


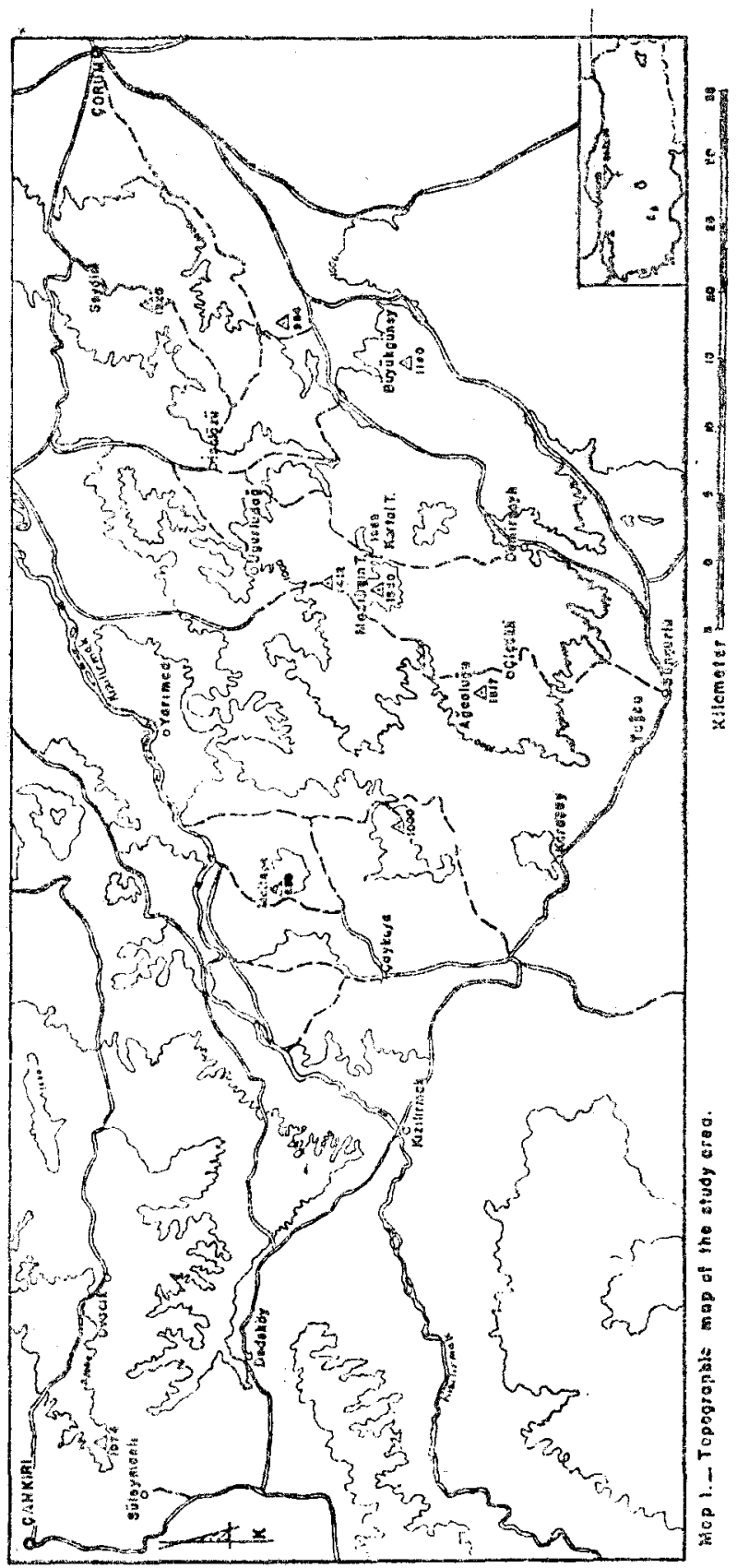


range of the area varies between $1000-1500$ meters, the highest peak reaches to 1585 meters (Kartal tepe).

The climatic conditions of the region are characterized by cold winter, often with frost and hot summer with drought periods. The data of the meteorological statations of Çankurı, Çorum, and Sungurlu and Bayat having only the precipitational measurements were used to determine the type of climate in the area. All the climatical data have been seen in the tables no 1-2-3-4-5-6-7. The total amount of rainfall in the region varies between $384.9-687.7 \mathrm{~mm}$. The mean minimum temperature of the coldest month $(\mathrm{m})$ is $-4.0^{\circ} \mathrm{C}$ in Çankırı and $-4.6^{\circ} \mathrm{C}$ in Çorum and the maximum ones of the hottest month varies from $29^{\circ} \mathrm{C}$ (in Çorum) to. $7^{\circ} \mathrm{C}$ (in Çankurı).

The bioclimatical values obtained by the present data are as follows:

\begin{tabular}{|cc|c|c|c|c|c|c|}
\hline \multicolumn{2}{|c|}{ Altitude (m) } & $\mathbf{p}(\mathrm{mm})$ & $\mathrm{M}\left({ }^{\circ} \mathrm{C}\right)$ & $\mathbf{m}\left({ }^{\circ} \mathrm{C}\right)$ & $\mathrm{Q}_{2}$ & $\mathrm{PE} / \mathrm{ME}$ & Type bioclimate \\
\hline Çankm & 751 & 384.9 & 30.7 & -4.0 & 38.7 & 2.2 & $\begin{array}{l}\text { Semi arid-very } \\
\text { cold type of } \\
\text { Corum }\end{array}$ \\
\hline
\end{tabular}

According to the pluviothermic quotient of Emberger (Q2), the area is under the influences of a semi arid-very-cold type of Mediterranean bioclimate.

\section{VEGETATION}

The study area situated in the peripheral zone of the Central Anatolia exhibites a vegetation which composed of decidious woody species and the steppe ones. In the study, the phytosociological structure of the woody communities was examined. As in the most of the world, the steppe vegetation peripherically delimited by sylvatic plant groups of Anatolian territory has been exploited by men particularly through grazing and intensive agricultural purposes. So it, here, is possible to see some degradation phases of vegetation types.

In the region two distinct group of woody vegetation can be mainly distinguished, one is of mediterranean origin and the others are Anatolian. Among these, the ones of medifeterranean origin are included in the class $Q$ uercetea ilicis and the others were attached 
Table 1. Monthly and annual mean temperature $\left({ }^{\circ} \mathrm{C}\right)$

\begin{tabular}{|l|c|c|c|c|c|c|c|c|c|c|c|c|c|c|}
\hline Stations & $\mathrm{h}(\mathrm{m})$ & $\mathrm{I}$ & $\mathrm{II}$ & $\mathrm{III}$ & $\mathrm{IV}$ & $\mathrm{V}$ & $\mathrm{VI}$ & VII & VIII & IX & $\mathrm{X}$ & $\mathrm{XI}$ & $\mathrm{XII}$ & Annual mean \\
\hline Cankin & 751 & -0.6 & 1.0 & 5.4 & 10.9 & 16.1 & 19.9 & 23.1 & 22.0 & 17.0 & 11.4 & 5.8 & 1.6 & 11.1 \\
\hline Corum & 798 & -0.6 & 1.1 & 4.8 & 10.5 & 15.1 & 18.5 & 21.1 & 21.0 & 17.0 & 12.1 & 6.6 & 1.8 & 10.7 \\
\hline
\end{tabular}

Table 2. Monchly and annual minimum mean temperature $\left({ }^{\circ} \mathrm{C}\right)$

\begin{tabular}{|l|r|c|c|c|c|c|c|c|c|c|c|c|c|c|}
\hline Stations & h(m) & I & II & III & IV & V & VI & VII & VIII & IX & X & XI & XII & Annual mean \\
\hline Çankun & 751 & -4.0 & -3.1 & -0.1 & 6.6 & 8.9 & 11.7 & 13.8 & 13.5 & 9.3 & 4.7 & 0.8 & -1.7 & 4.9 \\
\hline Çorum & 798 & -4.6 & -3.3 & -0.8 & 3.7 & 7.7 & 10.2 & 12.5 & 12.6 & 9.2 & 5.2 & 1.4 & -2.0 & 4.3 \\
\hline
\end{tabular}

Table 3. Monthly and annual maximum temperature $\left({ }^{\circ} \mathrm{C}\right)$

\begin{tabular}{|l|c|c|c|c|c|c|c|c|c|c|c|c|c|c|}
\hline Stations & $\mathrm{h}(\mathrm{m})$ & $\mathrm{I}$ & $\mathrm{II}$ & $\mathrm{III}$ & $\mathrm{IV}$ & $\mathrm{V}$ & $\mathrm{VI}$ & $\mathrm{VII}$ & $\mathrm{VIII}$ & $\mathrm{IX}$ & $\mathrm{X}$ & $\mathrm{XI}$ & $\mathrm{XII}$ & Annual mean \\
\hline Çankun & 751 & 3.3 & 5.5 & 11.3 & 17.6 & 22.7 & 26.6 & 30.5 & 30.7 & 25.8 & 20.0 & 12.6 & 5.6 & 17.7 \\
\hline Çorum & 798 & 3.8 & 6.0 & 11.0 & 17.2 & 22.1 & 25.7 & 28.7 & 29.0 & 24.9 & 19.9 & 13.2 & 6.2 & 17.3 \\
\hline
\end{tabular}


Table 4. Minimum temperature $\left({ }^{\circ} \mathrm{C}\right)$

\begin{tabular}{|l|r|c|c|c|c|c|c|c|c|c|c|c|c|c|}
\hline Stations & $\mathrm{h}(\mathrm{m})$ & $\mathrm{I}$ & $\mathrm{II}$ & $\mathrm{III}$ & $\mathrm{IV}$ & $\mathrm{V}$ & $\mathrm{VI}$ & $\mathrm{VII}$ & $\mathrm{VIII}$ & $\mathrm{IX}$ & $\mathrm{X}$ & $\mathrm{XI}$ & $\mathrm{XII}$ & Annual mean \\
\hline Çankmi & 751 & -25.0 & -24.0 & -15.5 & -4.7 & -22.6 & 1.6 & 6.4 & 4.6 & -2.0 & -6.3 & -19.4 & -17.7 & -25.0 \\
\hline Çorum & 798 & -25.6 & -25.5 & -19.0 & -7.8 & -3.0 & 0.2 & 4.0 & 3.0 & -3.0 & -6.3 & -21.5 & -24.4 & -25.6 \\
\hline
\end{tabular}

Table 5. Maximum temperature $\left({ }^{\circ} \mathrm{C}\right)$

\begin{tabular}{|l|c|c|c|c|c|c|c|c|c|c|c|c|c|c|}
\hline Stations & h(m) & I & II & III & IV & V & VI & VII & VIII & IX & X & XI & XII & Annual mean \\
\hline Çankur & 751 & 14.3 & 22.0 & 29.0 & 31.0 & 33.4 & 37.0 & 41.7 & 41.8 & 36.7 & 33.6 & 23.1 & 18.2 & 41.8 \\
\hline Çorum & 798 & 17.0 & 20.3 & 28.6 & 30.2 & 35.1 & 37.1 & 39.7 & 39.4 & 36.9 & 33.6 & 25.6 & 19.0 & 39.7 \\
\hline
\end{tabular}

Table 6. Mean relative humidity \%

\begin{tabular}{|l|c|c|c|c|c|c|c|c|c|c|c|c|c|c|}
\hline Stations & $\mathrm{h}(\mathrm{m})$ & $\mathrm{I}$ & II & III & IV & V & VI & VII & VIII & IX & X & XI & XII & Annaal mean \\
\hline Çankur & 751 & 79 & 75 & -67 & 62 & 62 & 57 & 52 & 52 & 59 & 65 & 73 & 80 & 65 \\
\hline Çorum & 798 & 76 & 74 & 67 & 62 & 61 & 57 & 52 & 53 & 57 & 62 & 70 & 77 & 64 \\
\hline
\end{tabular}


Table 7. Monthly and annual mean precipitation

\begin{tabular}{|c|c|c|c|c|c|c|c|c|c|c|c|c|c|c|}
\hline Stations & I & II & III & IV & $\mathbf{V}$ & VI & VII & VIII & $\mathbf{I X}$ & $\mathrm{X}$ & $\mathbf{X I}$ & XII & $\begin{array}{l}\text { annual } \\
\text { mean } \\
\text { precip. }\end{array}$ & $\begin{array}{c}\text { the } \\
\text { regine } \\
\text { of precip. }\end{array}$ \\
\hline Çankim & 46.0 & 38.3 & 37.8 & 38.9 & 55.0 & 39.9 & 13.0 & 13.3 & 15.1 & 17.1 & 23.5 & 47.2 & 384.9 & $\mathrm{Sp}, \mathbf{W}, \mathrm{Sm}, \mathbf{A}$ \\
\hline Çorum & 44.4 & 31.2 & 38.1 & 46.1 & 60.9 & 47.5 & 17.7 & 12.9 & 19.5 & 25.0 & 30.6 & 43.8 & 417.7 & $|\mathrm{sp}, \mathbf{W}, \mathbf{S m}, \mathbf{A}|$ \\
\hline
\end{tabular}

Table 8. Soil analysis

\begin{tabular}{|c|c|c|c|c|c|c|c|c|c|c|c|c|c|}
\hline \multicolumn{7}{|c|}{ Physical Analysis } & \multicolumn{7}{|c|}{ Chemical Analysis } \\
\hline \multirow{2}{*}{$\begin{array}{l}\text { Plant } \\
\text { Group }\end{array}$} & \multirow{2}{*}{$\begin{array}{l}\text { gyp- } \\
\text { sum }\end{array}$} & \multirow{2}{*}{$\underset{\%}{\mathrm{CaCO}_{3}}$} & \multirow[b]{2}{*}{ Sand } & \multirow[b]{2}{*}{ Silt } & \multirow[b]{2}{*}{ Clay } & \multirow{2}{*}{$\begin{array}{c}\text { Texture } \\
\text { class }\end{array}$} & \multirow[b]{2}{*}{$\mathrm{pH}$} & \multirow{2}{*}{$\begin{array}{c}\text { Conduc- } \\
\text { tance } \\
\text { m.mhos } / \mathrm{cm}\end{array}$} & \multicolumn{5}{|c|}{ Soluable Cations meq/lt. } \\
\hline & & & & & & & & & $\mathrm{Mg}$ & $\mathrm{Ca}$ & $\mathrm{Ca}+\mathrm{Mg}$ & $\mathbf{N}$ & $\mathbf{K}$ \\
\hline $\begin{array}{l}\text { Carici- } \\
\text { Quercetum }\end{array}$ & 一 & 0.7 & 67.43 & 26.26 & 6.30 & $\begin{array}{l}\text { Sandy- } \\
\text { Loam }\end{array}$ & 7.6 & 0.770 & 2.6 & 4.8 & 7.4 & 0.130 & 0.090 \\
\hline $\begin{array}{l}\text { Carici- } \\
\text { Quercetum }\end{array}$ & - & 0.6 & 47.23 & 50.14 & 2.62 & $\begin{array}{l}\text { Silty- } \\
\text { Loam }\end{array}$ & 7.4 & 0.774 & 1.4 & 5.9 & 7.3 & 0.102 & 0.086 \\
\hline
\end{tabular}


to the class $Q$ uercetea pubescentis. These units were classified by ordinating the quadrats according to the three dimensional ordination technique of Bray and Curtis, 1957 (Figure no 1).

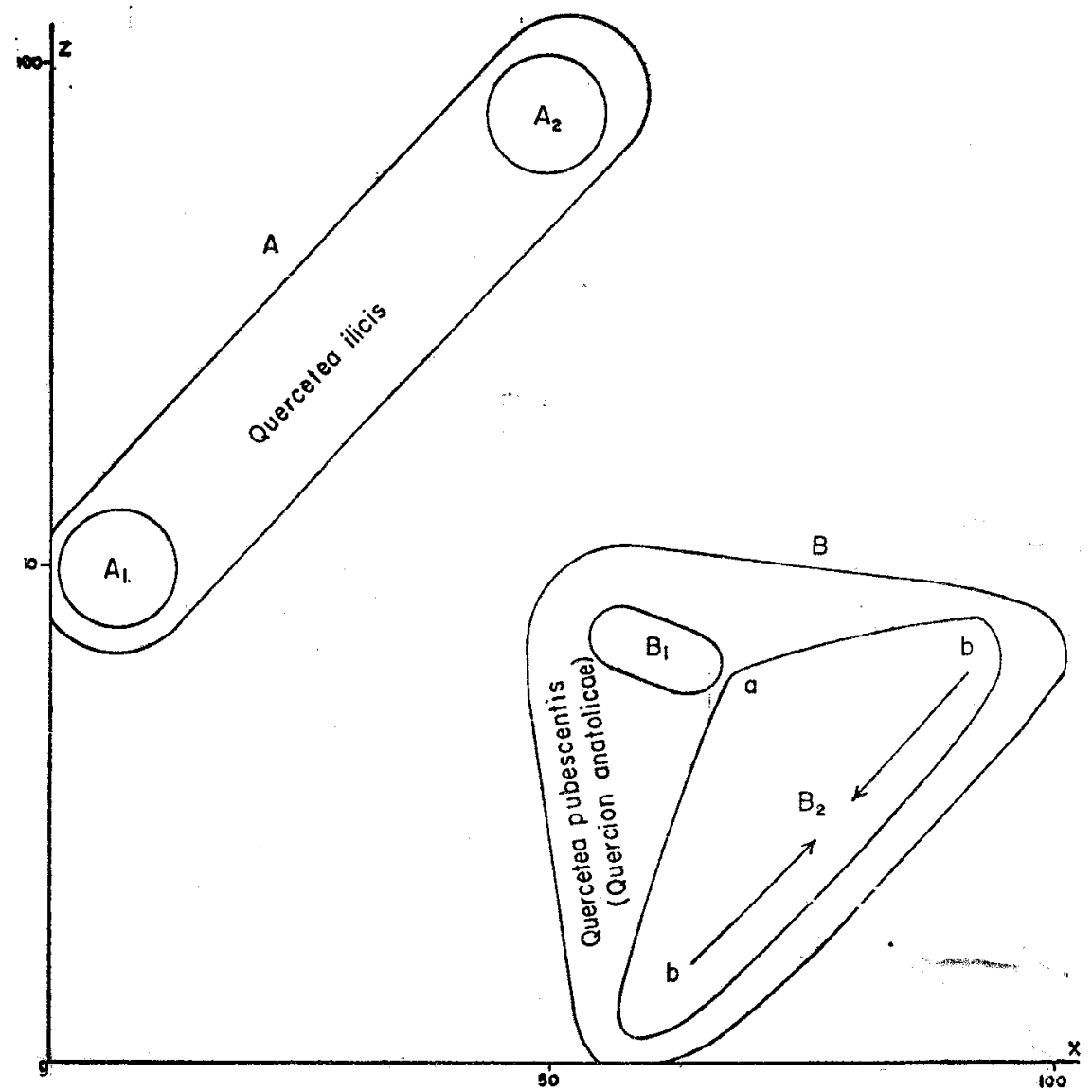

Figure 1. Ordination of the Plants associations. $A_{2}-$ Juniperus excelsa Plant group, $A_{1}-$ Salvio -Rhoetum coriariae, $B_{1}$ - Carici-Pinetum nugrae, $B_{2}$ - Carici-Quercetum cerridis a) quercetosum pubescentis, b) quercetosum macrantherae.

Class: Quercetea ilicis Br.-Bl. $1936 \mathrm{em}$.

Rivas-Martinez 1975

The mediterranean originated plants groups spreading around Harami stream between the towns of Çorum and Bayat have been classified in two units. 
a) Juniperus excelsa-Paliurus spina-christi plant group (Table no 1)

Although it can be differentiated by the mediterranean species such as Juniperus excelsa and Paliurus spina-christi, this community was considered, for now, as a plant group instead of association due to its local distribution. It is a woody community composed of the steppe and sylvatic species and it occupies the sites in the form of stream beds with an altitude of $950 \mathrm{~m}$. Although its phytosociological interpretation is diffucult, the plant group is included in the class $Q$ u e r ce $t$ e a $i l i c$ is due to the dominancy of the species of mediterranean origin.

b) Salvio-Rhoetum coriariae ass.nova (Table no 1)

Characteristic and differantial species :

Rhus coriaria, Salvia heldreichiana,

\section{Habitat and structure:}

This is an association which occupies the same site of $800 \mathrm{~m}$ as the previous one and spreads out on the hills with an inclination of $40 \%$. Salvia heldreichiana plays a co-dominant role in this association dominated by Rhus coriaria. The soil surface have a stony appearance due to the erosion. The coverage percentage of the association is about $50 \%$. The components of the floristic composition along with the characteristic species belongs to the syntaxa of mediterranean origin.

\section{Distribution :}

The association has a local distribution in the area.

\section{Syntaxonomy :}

The association was considered in the lass $Q$ u e r cete a il i c is extending in the whole mediterranean region due to the phytogeoraphical characteristics of the species.

Holotype: Table no 1 quadrat no 59.

Class: Q u ercrte a pubescentis Oberd. 1948; Doing Kraft 1955.

Order: Q u e r c o-C a r p in e t a li a Quézel, Barbéro, Akman 1980 Alliance: $Q$ u excion an a t o lic a e Quézel Barbéro, Akman 1977 
Table 1: Plant communities of the Class Quercetea ilicis

\begin{tabular}{|c|c|c|c|c|c|c|c|c|}
\hline 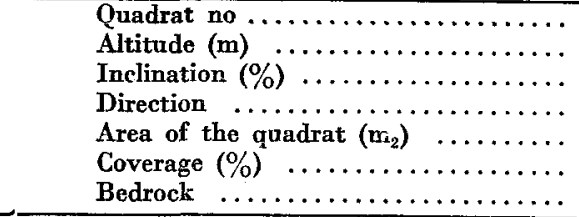 & $\begin{array}{r}54 \\
950 \\
0 \\
\mathrm{~N} \\
100 \\
40 \\
\mathrm{CM}\end{array}$ & $\begin{array}{r}55 \\
950 \\
0 \\
\mathrm{~N} \\
100 \\
40 \\
\mathrm{CM}\end{array}$ & $\begin{array}{r}56 \\
950 \\
0 \\
N \\
100 \\
40 \\
\mathrm{CM}\end{array}$ & $\begin{array}{r}57 \\
800 \\
40 \\
\mathrm{~S} \\
100 \\
50 \\
\mathrm{C}\end{array}$ & $\begin{array}{r}58 \\
800 \\
40 \\
\mathrm{~S} \\
100 \\
50 \\
50\end{array}$ & $\begin{array}{r}59 \\
800 \\
40 \\
\mathrm{~S} \\
100 \\
50 \\
\mathrm{C}\end{array}$ & $\begin{array}{r}60 \\
800 \\
40 \\
\mathrm{~S} \\
100 \\
50 \\
\mathrm{C}\end{array}$ & 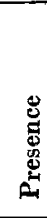 \\
\hline \multicolumn{9}{|l|}{ Characreristic and differantial species: } \\
\hline 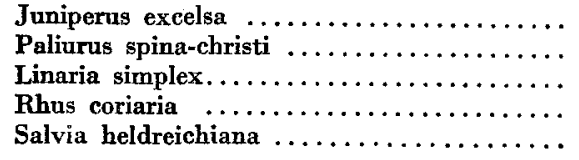 & $\begin{array}{r}33 \\
23 \\
+1 \\
. \\
\end{array}$ & $\begin{array}{r}33 \\
12 \\
+1-1 \\
. \\
.\end{array}$ & $\begin{array}{r}33 \\
23 \\
+1 \\
. \\
.\end{array}$ & $\begin{array}{r}\dot{.} \\
3 \dot{3} \\
22\end{array}$ & $\begin{array}{r}\dot{.} \\
33 \\
22\end{array}$ & $\dot{.}$ & $\begin{array}{r}. \\
. \\
33 \\
23\end{array}$ & $\begin{array}{l}\text { III } \\
\text { III } \\
\text { III } \\
\text { IV } \\
\text { IV }\end{array}$ \\
\hline \multicolumn{9}{|l|}{ Characteristics of the Quercetea ilicis: } \\
\hline $\begin{array}{l}\text { Juniperus oxycedrus } \ldots \ldots \ldots \ldots \ldots \ldots \ldots \\
\text { Cotoneaster nummularium } \quad \ldots \ldots \ldots \ldots \ldots \\
\text { Characteristics of the Quercetea pubescentis: }\end{array}$ & $\begin{array}{r}12 \\
++\end{array}$ & $\begin{array}{r}+1 \\
11\end{array}$ & $\begin{array}{l}12 \\
11\end{array}$ & $\cdot$ & . & . & & $\begin{array}{l}\text { III } \\
\text { III }\end{array}$ \\
\hline $\begin{array}{l}\text { Berberis crataegyna } \ldots \ldots \ldots \ldots \ldots \ldots \ldots \ldots \ldots \\
\text { Quercus pubescens } \ldots \ldots \ldots \ldots \ldots \ldots \ldots \ldots \ldots \\
\text { Characteristics of the Querco-Fagea and } \\
\text { Querco-Fagetea: }\end{array}$ & \multicolumn{8}{|c|}{$\begin{array}{l}\text { Characteristics of the Querco-Fagea and } \\
\text { Querco-Fagetea: }\end{array}$} \\
\hline \multicolumn{9}{|l|}{$\begin{array}{l}\text { Characteristics of the Astragalo-Brometea and } \\
\text { Oaobry cho armeni-Thymetalia lencostomi: }\end{array}$} \\
\hline 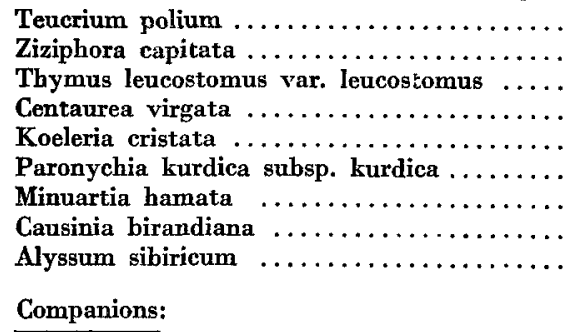 & $\begin{array}{r}\dot{ } \\
\dot{.} \\
\dot{+} \\
+1\end{array}$ & $\begin{array}{r}+1 \\
\dot{.} \\
\dot{11} \\
+1 \\
+\dot{1}\end{array}$ & $\begin{array}{r}+1 \\
\dot{.} \\
\dot{1} \\
+1 \\
+1 \\
+1\end{array}$ & $\begin{array}{r}+1 \\
++1 \\
+1 \\
+1 \\
. \\
. \\
.\end{array}$ & $\begin{array}{r}+1 \\
++1 \\
+1 \\
+1 \\
11 \\
0 \\
0 \\
.\end{array}$ & $\begin{array}{r}11 \\
+1 \\
+1 \\
+1 \\
+1 \\
. \\
. \\
.\end{array}$ & $\begin{array}{r}+1 \\
++ \\
+1 \\
+1 \\
11 \\
. \\
.\end{array}$ & $\begin{array}{l}\text { V } \\
\text { IV } \\
\text { IV } \\
\text { IV } \\
\text { III } \\
\text { III } \\
\text { III } \\
\text { II } \\
\text { II }\end{array}$ \\
\hline 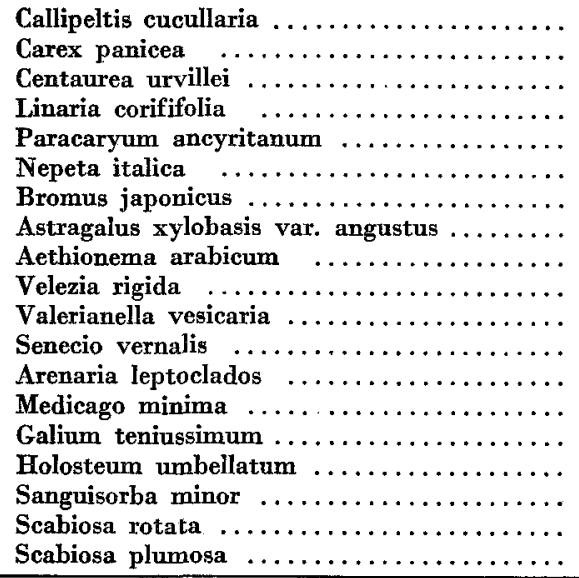 & $\begin{array}{r}+1 \\
. \\
. \\
. \\
. \\
+1 \\
+1 \\
+1 \\
++ \\
++ \\
++ \\
+1 \\
+1 \\
. \\
.\end{array}$ & $\begin{array}{r}+1 \\
. \\
. \\
. \\
. \\
+1 \\
+1 \\
++ \\
++ \\
++ \\
++ \\
+1 \\
+1 \\
++ \\
+1\end{array}$ & $\begin{array}{r}+1 \\
. \\
. \\
. \\
. \\
+1 \\
+1 \\
+1 \\
+1 \\
+1 \\
++ \\
+1 \\
11 \\
++ \\
+1\end{array}$ & $\begin{array}{r}+1 \\
+1 \\
++ \\
+1 \\
++ \\
+1 \\
. \\
. \\
. \\
. \\
. \\
. \\
. \\
.\end{array}$ & $\begin{array}{r}+1 \\
+1 \\
++ \\
+1 \\
++ \\
+1 \\
+1 \\
+1 \\
. \\
. \\
. \\
. \\
. \\
. \\
. \\
.\end{array}$ & $\begin{array}{r}+1 \\
+1 \\
++ \\
+1 \\
++ \\
+1 \\
+1 \\
+1 \\
. \\
. \\
. \\
. \\
. \\
. \\
. \\
+ \\
+\end{array}$ & $\begin{array}{r}+1 \\
+-1 \\
++ \\
++ \\
+1 \\
+1 \\
+1 \\
11 \\
\cdot \\
\cdot \\
\cdot \\
\cdot \\
\cdot \\
\cdot \\
\cdot \\
+\end{array}$ & $\begin{array}{l}\text { V } \\
\text { IV } \\
\text { IV } \\
\text { IV } \\
\text { IV } \\
\text { IV } \\
\text { III } \\
\text { III } \\
\text { III } \\
\text { III } \\
\text { III } \\
\text { III } \\
\text { III } \\
\text { III } \\
\text { III } \\
\text { III } \\
\text { II } \\
\text { II } \\
\text { II }\end{array}$ \\
\hline
\end{tabular}

$$
\begin{aligned}
\text { C : Calcareous } \\
\text { M : Marl }
\end{aligned}
$$


Carici-Quercetum cerridis ass. nova (Table no 2).

Characteristics and differantial species:

Quercus cerris var. cerris, Carex divisula var. leersii.

Habitat and structural characterictics:

In the study area, the decidious forest are formed by Quercus cerris var. cerris, Quercus pubescens subsp. anatolica and Quercus macranthera subsp. syspirensis. Quercus cerris var. cerris is a dominant spesies in the area and the others are co-dominant ones. These types of forests are especially widespread in the sites of $1550-1500 \mathrm{~m}$. where the rainfall increases.

This association which is described through 19 quadrats is characterized by Quercus cerris var. cerris and Carex divisula subsp. leersii and is spread out on the soils derivated from calcereous mainrock $(\mathrm{pH}$ : 7.4-7.6).

The soils on which the association is spread out has a sandy and loamy clayey texture as seen in the table no 8 .

The floristic composition of these forests is nearly heterogeneous although they have an homogeneous aspect from the physionomical point of view.

According to the co-dominant species, characteristics and exposition, two subassociations can be distinguished;

1-Quercetosum pubescentis

This subassociation which is differentiated by Querercus pubescens subsp. anatolica and Vicia grandiflora var. grandiflora is individualized on the south slopes of the Uğurludağ.

2-Quercetosum macrantherae

Especially Quercus macrathera subsp. sispyrensis and Telephium imperati play an important reole as a differantial species in this subassociation.

\section{Distribution :}

This association is widespread on the north slopes of Uğurludağ between Çorum and Bayat. 


\section{Syntaxonomy :}

The association were included in the alliance $Q u$ e $r$ cion a natolicae of the order Querco-Carpinetalia belonging to the superclass $Q$ u e r c o-F a g e a. The species of the class A s i r a. g a l o-B r o m e t e a don't play an imporatant role here.

Holotype: Table no 2, quadrat no 80

\section{Carici-Pinetum nigrae}

(Table no 3)

Habitat and structural characteristics :

The black pine association covers a narrower area in the region than that of Oaks.

The association is characterized by Pinus nigra subsp. pallasiana, Carex distachya, Anihyllis vulneraria subsp. boissieri, Lathyrus spathulatus, Epipactis helleborine and Campanula rapunculoides.

This association which is localized around Uğurludağ display a degraded structure while the tree layer is composed of the type species Pinus nigra subsp. pallasiana, Quercus pubescens subsp. anatolica, Quercus cerris var. cerris and Colutea cilicica forms the scrub layer. The grassy layer is composed of some the steppe species.

In the area, the northern slopes between 1000-1050 m. are occupied by this association.

Although steppe species and sylvatic ones were found together in the area because of its phytogeogrophical situation, this association is more homogenous than the previous one from the physiognomic and floristic point of view.

\section{Distribution :}

Uğurludağ, Hacılarhanı and Misler ovası are occupied by this association.

\section{Syntaxonomy:}

In the study area, this association were considered in the class Quercetea pubescentis and in its alliance $Q u e r c i o n$ an atolicae. 


\begin{tabular}{|c|c|c|c|c|c|c|c|c|c|c|c|}
\hline 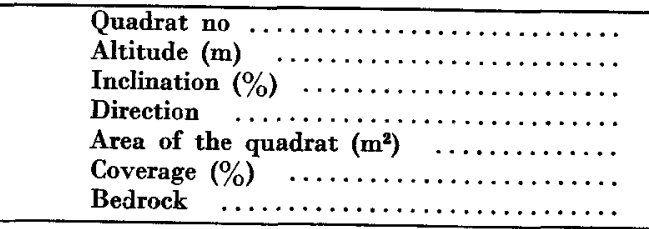 & $\begin{array}{r}43 \\
1100 \\
30 \\
\mathrm{~N} \\
1000 \\
60 \\
\mathrm{C}\end{array}$ & $\begin{array}{r}44 \\
1100 \\
30 \\
N \\
1000 \\
60 \\
\mathrm{C}\end{array}$ & $\begin{array}{r}45 \\
1150 \\
25 \\
\mathrm{~N} \\
1000 \\
70 \\
\mathrm{C}\end{array}$ & $\begin{array}{r}46 \\
1050 \\
20 \\
N \\
1000 \\
60 \\
\mathrm{C}\end{array}$ & $\begin{array}{r}47 \\
1100 \\
25 \\
N \\
1000 \\
60 \\
\mathrm{C}\end{array}$ & $\begin{array}{r}76 \\
1100 \\
5 \\
5 E \\
1000 \\
60 \\
\mathrm{C} \\
\end{array}$ & $\begin{array}{r}65 \\
1000 \\
5 \\
N V^{-} \\
1000 \\
40 \\
\mathrm{C}\end{array}$ & $\begin{array}{r}48 \\
1150 \\
20 \\
\mathrm{~N} \\
1000 \\
70 \\
\mathrm{C}\end{array}$ & $\begin{array}{r}49 \\
1100 \\
20 \\
\mathrm{~N} \\
1000 \\
60 \\
\mathrm{C}\end{array}$ & $\begin{array}{r}50 \\
1100 \\
30 \\
\mathrm{~N} \\
1000 \\
60 \\
\mathrm{C} \\
\end{array}$ & 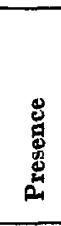 \\
\hline \multicolumn{12}{|l|}{ Characteristic and differential species of the association: } \\
\hline 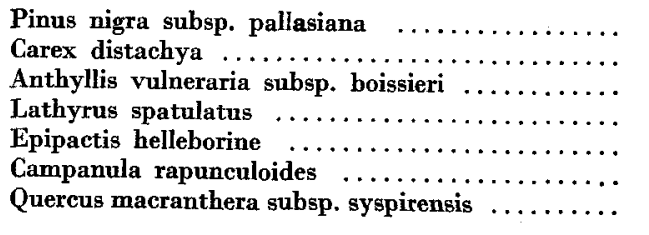 & $\begin{array}{r}33 \\
+1 \\
. \\
. \\
.\end{array}$ & $\begin{array}{l}33 \\
11\end{array}$ & $\begin{array}{r}34 \\
+1 \\
+1 \\
. \\
. \\
.\end{array}$ & $\begin{array}{r}33 \\
11 \\
+1 \\
+\end{array}$ & $\begin{array}{r}34 \\
11 \\
+1 \\
+ \\
+ \\
+ \\
.\end{array}$ & $\begin{array}{l}33 \\
: \\
: \\
:\end{array}$ & \begin{tabular}{c|c}
33 \\
22 \\
$\cdot$ \\
$\cdot$ \\
$\cdot$ \\
$\cdot$
\end{tabular} & $\begin{array}{r}44 \\
11 \\
+1 \\
++ \\
+1 \\
+1 \\
+1\end{array}$ & $\begin{array}{r}44 \\
12 \\
11 \\
++ \\
+1 \\
+1 \\
+1\end{array}$ & $\begin{array}{r}44 \\
+1 \\
11 \\
+1 \\
+1 \\
+1 \\
+1\end{array}$ & $\begin{array}{l}\text { V } \\
\text { V } \\
\text { III } \\
\text { III } \\
\text { II } \\
\text { II } \\
\text { II }\end{array}$ \\
\hline \multicolumn{12}{|l|}{ Characteristics of the Quercion anatolicae: } \\
\hline $\begin{array}{l}\text { Coronilla varia } \ldots \ldots \ldots \ldots \ldots \ldots \ldots \ldots \ldots \\
\text { Quercus pubescens subsp. anatolica } \ldots \ldots \ldots \ldots \ldots \ldots \\
\text { Vicia cracca subsp. stenophylla } \ldots \ldots \ldots \ldots \ldots \ldots\end{array}$ & +1 & 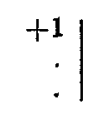 & $\dot{r}$ & $\begin{array}{r}+1 \\
.\end{array}$ & $\begin{array}{c}+1 \\
++1 \\
+1\end{array} \mid$ & 12 & 12 & $\dot{1}$ & $\begin{array}{r}+1 \\
.\end{array}$ & $\begin{array}{r}+1 \\
12\end{array}$ & $\begin{array}{r}\text { III } \\
\text { II } \\
\text { I }\end{array}$ \\
\hline \multicolumn{12}{|l|}{ Characteristics of Quercetea pubescentris: } \\
\hline 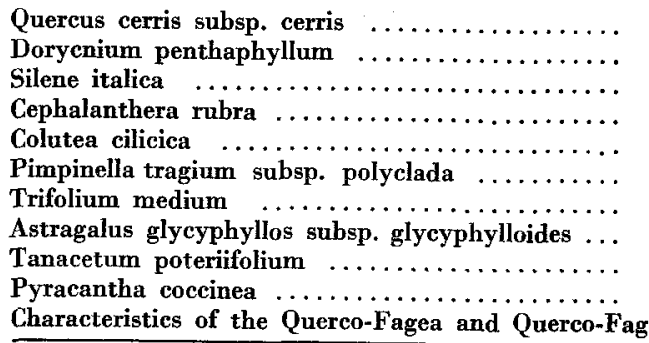 & $\begin{array}{l}\dot{\bullet} \\
\dot{.} \\
\dot{.} \\
\dot{.}\end{array}$ & $\begin{array}{r}+i \\
\dot{ }\end{array}$ & $\begin{array}{r}+ \\
+1 \\
+1 \\
. \\
. \\
. \\
.\end{array}$ & $\begin{array}{c}+1 \\
22 \\
+1 \\
+ \\
+ \\
\end{array}$ & $\begin{array}{r}+1 \\
+1 \\
+1 \\
+ \\
+ \\
+1 \\
. \\
.\end{array}$ & $\begin{array}{r}12 \\
++ \\
11\end{array}$ & $\begin{array}{l}12 \\
\dot{5} \\
\dot{5} \\
\dot{.}\end{array}$ & $\begin{array}{l}+1 \\
+1 \\
+1 \\
+ \\
+ \\
+1 \\
11\end{array}$ & $\begin{array}{r}+1 \\
+1 \\
11 \\
+ \\
+ \\
+1 \\
+1 \\
+1 \\
.1\end{array}$ & $\begin{array}{r}12 \\
+1 \\
+1 \\
+ \\
+i \\
+1 \\
+i \\
+ \\
+\end{array}$ & $\begin{array}{r}\text { V } \\
\text { IV } \\
\text { III } \\
\text { III } \\
\text { II } \\
\text { II } \\
\text { II } \\
\text { I } \\
\text { I } \\
\text { I }\end{array}$ \\
\hline 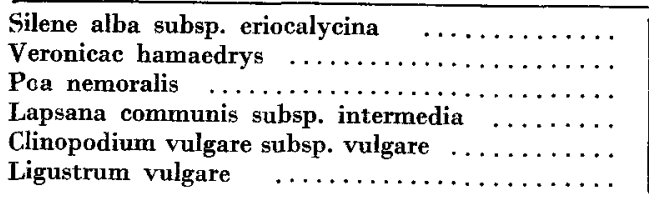 & $\begin{array}{r}+ \\
+1 \\
. \\
.\end{array}$ & $\begin{array}{c}+ \\
+1 \\
+\end{array}$ & $\begin{array}{r}+ \\
+1 \\
+1 \\
.\end{array}$ & $\begin{array}{c}+ \\
11 \\
11\end{array}$ & $\begin{array}{r}+ \\
+1 \\
11\end{array}$ & $\begin{array}{r}+1 \\
+1 \\
+\end{array}$ & $\dot{.}$. & $\begin{array}{r}+ \\
+1 \\
+1 \\
+1\end{array}$ & $\begin{array}{r}+ \\
11 \\
11 \\
+1 \\
+1\end{array}$ & $\begin{array}{r}+ \\
11 \\
11 \\
+1 \\
+ \\
+\end{array}$ & $\begin{array}{r}\text { IV } \\
\text { IV } \\
\text { IV } \\
\text { II } \\
\text { I } \\
\text { I }\end{array}$ \\
\hline \multicolumn{12}{|c|}{ Characteristics of Astragalo-Brometea and Onobrycho armeni-Thymetalia leucostomi: } \\
\hline 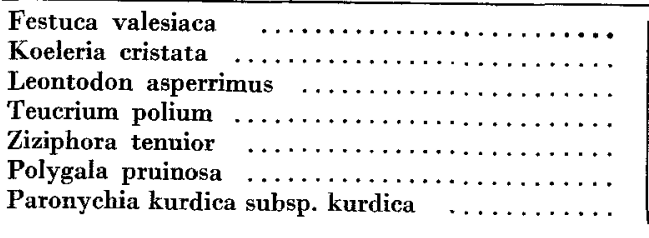 & ++ & $\begin{array}{l}+1 \\
+1 \\
+ \\
+ \\
+1 \\
+1\end{array}$ & $\begin{array}{r}+1 \\
+1 \\
+ \\
+ \\
++ \\
+1 \\
+\end{array}$ & $\begin{array}{r}11 \\
+1 \\
+ \\
++ \\
\\
+\end{array}$ & $\begin{array}{r}+1 \\
+1 \\
+1 \\
+1 \\
++ \\
+1\end{array}$ & $\begin{array}{r}11 \\
+1 \\
\dot{1} \\
\dot{12}\end{array}$ & $\begin{array}{l}23 \\
12\end{array}$ & $\begin{array}{c}+1 \\
+1 \\
+ \\
+1 \\
++ \\
.\end{array}$ & $\begin{array}{r}11 \\
+ \\
+ \\
+1 \\
+1 \\
+1\end{array}$ & $\begin{array}{c}+1 \\
+1 \\
+ \\
+1 \\
++ \\
+1\end{array}$ & $\begin{array}{l}\text { V } \\
\text { IV } \\
\text { IV } \\
\text { IV } \\
\text { III } \\
\text { III } \\
\text { I }\end{array}$ \\
\hline \multicolumn{12}{|l|}{ Compenions: } \\
\hline 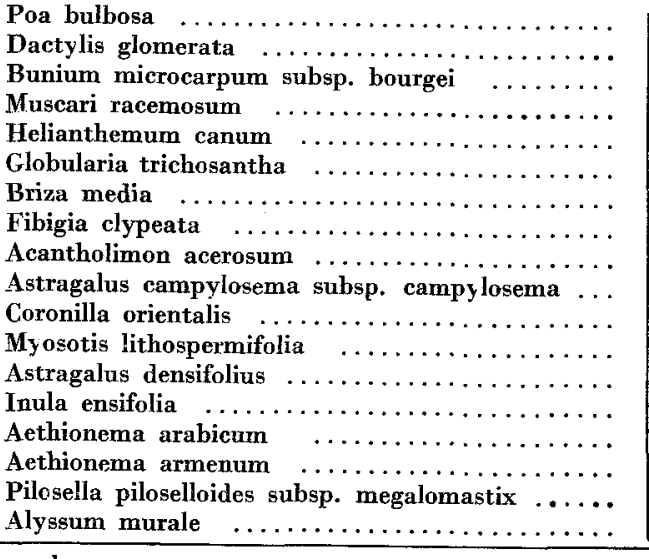 & $\begin{array}{r}+1 \\
++ \\
+1 \\
+ \\
+1 \\
11 \\
+1 \\
+1 \\
11\end{array}$ & $\begin{array}{l}++ \\
++ \\
++ \\
+ \\
22 \\
+1 \\
+1 \\
++ \\
12 \\
+1 \\
+\end{array}$ & $\begin{array}{r}11 \\
++ \\
++ \\
+1 \\
12 \\
+1 \\
+1 \\
++ \\
11 \\
+ \\
+1 \\
+1\end{array}$ & $\begin{array}{r}11 \\
+1 \\
++ \\
11 \\
22 \\
+1 \\
11 \\
++ \\
+ \\
+1 \\
+1 \\
+1 \\
11 \\
+1\end{array}$ & $\begin{array}{r}11 \\
+1 \\
++ \\
+1 \\
22 \\
11 \\
+1 \\
++ \\
+1 \\
11 \\
+1 \\
+1 \\
+1 \\
+\end{array}$ & $\begin{array}{l}11 \\
. \\
. \\
. \\
. \\
. \\
. \\
. \\
.\end{array}$ & $\begin{array}{l}+1 \\
22 \\
+1\end{array}$ & $\begin{array}{c}11 \\
+1 \\
+ \\
+1 \\
+1 \\
11 \\
+1 \\
+ \\
+1 \\
+1 \\
+ \\
+1 \\
+1 \\
+1\end{array}$ & $\begin{array}{r}11 \\
+1 \\
+ \\
+1 \\
11 \\
+1 \\
++ \\
+ \\
+1 \\
11 \\
+ \\
+1 \\
+1 \\
+1 \\
+ \\
+1 \\
+1 \\
+1\end{array}$ & $\begin{array}{r}+1 \\
+1 \\
+1 \\
+1 \\
+1 \\
+1 \\
11 \\
+1 \\
+1 \\
+1 \\
11 \\
+1 \\
+1 \\
+ \\
+ \\
+ \\
.\end{array}$ & $\begin{array}{l}\text { V } \\
\text { V } \\
\text { V } \\
\text { V } \\
\text { IV } \\
\text { IV } \\
\text { IV } \\
\text { IV } \\
\text { IV } \\
\text { III } \\
\text { III } \\
\text { III } \\
\text { III } \\
\text { III } \\
\text { II } \\
\text { II } \\
\text { I } \\
\text { I }\end{array}$ \\
\hline
\end{tabular}


However some steppe species which belongs to the A s t r a g a 1 o -B rom et e a can also be seen here, they don't have a phytosociological significance Holotype: Table no 3, Quadrat no 47.

\section{DISCUSSION}

The study area situated in the nort-east part of the peripheral zone of the Central Anatolia is phytogeographically localized in IranoAnatolian floristic region.

The associations described here were considered in the following syntaxa;

Superclass: Qu erco-Fa ge a Fukaret et Fabi-Janik 1968

Class : Quercetea pubescentis Oberd. 1948; Doing Kraft 1955

Order : Q u e r co-Carpin et a li a Quezēl, Barbēro, Akman 1980

Alliance : Quercion a nat olicae Quezell, Barbēro, Akman 1977

Class : Quercetea ilicis Br.-Bl. 1936 em RivasMartinez 1975

Quercetea pubescentis:

Its borders are extended from the Mediterranean to Eurosiberian region in the north. This class has been divided into two orders, one of them is $Q u e r c r t a l i a p u b e s c e n t i s$ and the other $Q u e r c o$ - Cedretalia libani.

The recent researches proved that $Q u$ ercetalia $p u b$ esc e $n$ t is should be considered together with the $Q$ u erco-C a r p i$\mathrm{n}$ et a li a owing to its special alliances. This order is represented by the alliance of $Q$ uercion anatolicae in the region.

Quercetea ilicis:

This class extends to whole Mediterranean basin, from Greece to the near east. A lot of sclerophyllous and also decidious species were included in this class. Several plant groups which belong to this class were attached to the order $Q u$ ercetalia ilicis. 
Class : Quercetea ili cis

Juniperus excelsa-Paliurus spina-christi plant group:

In Turkey, Juniperus excelsa is generally common in the Mediterranean phytogeographical region, in steppe-forest transitional belt of Central Anatolia and at low levels of Prepontic region in norch Anatolia of between 1000-1200 meters. These forest types indicating a degratation phase in vast part of Anatolia are under the effects of man in various ways such as excessive grazing and extensive farming. This kind of effects caused some steppe species to panetrate into its floristic composition. The same situation was observed in the study area. Juniperus excelsa was thought as a plant group instead of plant association because of its local distribution and floristics aspect. Due to the fact that some differantial and dominant species except for the steppe ones belong to the $Q u$ ercetea ilicis, this group was considered in this class.

The same plant group had been determined by Quezel et all. (1980) in north Anatolia, Getik (1976) in Elmall, Ovacakverdi (1983) in Seydişehir and Kılınৎ̧ (1985) in Devrez Kızilırmak region.

Salvio-Rhoetum coriaria:

Rhus coriaria is a Mediterranean element but it has a large ecological range that is why it is widespread on the eroded red-brown calcareous soils.

This association is characterized by the Mediterranean originated species. The large number of the components forming its floristic composition comprise of steppe species. However, this association was considered in the class of $Q$ u er cete a $i 1$ i c $i s$, due to its characteristics and differantial spesies. There is not a smillarity between E p h edro-R h o t u m c oriaria e determined by Cetik (1985) in Aksaray and this association described here due to the their distinct geographical distributions.

Class : Quercetea pubescentis

Alliance : Quercion anatolica

Carici-Pinetum nigrae:

Pinus nigra subsp. pallasiana is more widespread than the other pine species in Turkey. This plant group forms local communuties ni 
the area which is situated transitional zone of steppe and forest in Central Anatolia of between 1000-1150 meters.

This sylvatic group was researched by indigenous and foreign researchers in vast part of Turkey so far.

The black pine communuties were considered within the alliance Pinion nigra e by Zohary (1973) owing to the fact that they showed an ecological and floristical pecularities in different geographical regions.

This alliance was seperated into two groups by the author; $P$ i $n$ i o $n$ $\mathrm{nigrae}$ orientale which is located in the Oromediterranean zone of Mediterranean region and $P$ in io $n$ ig $r$ a $x$ ero-e $u$ i $\mathrm{n} \mathrm{m}$ which is spreading out in the Xero-Euxinion zone of Central Anatolia. The other black pine communuties determined in the north of Armutlu around Izmir were considered as $P$ in et $\mathbf{u}$ m $n$ igra e t y p i c u by Schwarz (1936). On the other hand a group of this community in Anatolia was attached to the order Q u e r c o-C e d rt a li a $l i b$ a $\mathrm{n}$ which is common in the Mediterranean region and the others were attached to $Q$ u e r c o-C a r pin e t a li a by Akman, Quezēl and Barbēro (1978) due to the its ecological and floristical differences.

In this study, this association has been included in the alliance Quercion anatolicae of the class Quercetea pubescentis.

\section{Carici-Quercetum Cerridis:}

The communities of Quercus cerris which is a Mediterranean element were described with local species by Cetik (1985) in Erciyes mountain, by Düzenli (1976) in Hasan mountain and Vural et all. (1985) in National park of Afyon.

In the area, Quercus cerris showing a large distribution forms an association in which Quercus pubescens and Quercus macrenthera were appeared as co-dominant species in different expositions. Two distinct subassociations were formed by two oak species within the association characterized by Quercus cerris and Carex divisula. In the association, although some species of Astragalo-Brometea were increased in number because of its phytogeographical situation, They 
don't play any important role from the point of phystosociological view.

\section{REFERENCES}

AKMAN, Y. and DAGET, Ph. 1971. Quelcues aspects synoptiques des climats de la Turquie. Bull. Soc. Lang. Géogr. Tome 5. Fase. 3.

AKMAN, Y. 1974. Etude phytosociologique de la région de Beypazarı Karaşar et Nallıhan. Com. de la Fac. Sc. d'Ank. Sere Z. Tome $18 \mathrm{C}$.

AKMAN, Y. YURDAKULOL, E. AYDOĞDU, M. 1983. A phytosociological research on the vegetation of the Bolu mountains. Communs Fac. Se. Univ. Ank. C 1/ 7: 87-104.

BARBERO, M. and QUEZEL, P. 1977. Les groupements forestieres de la Gréce Centro-Méridionale. Ecologia Mediterranea II. Marseille.

BRAUN-BLANQUET, J. 1932. Plant sociology (translated by Fuller and Conard) New York, London.

BRAY, J.R. and CURTIS, J.T. 1975. An ordination of the upland forest communities of Southern Wisconsin. Ecol. Monog. 27: 325-349.

CAMPBELL, B.M. 1978. Similarity coefficients for classifying relevés. Vegetatio 37 (2): 101-109.

Cankurı ve Çorum toprak kaynağı envanter haritası. TC. Köy İ̧̧leri Bakanlığı Topraksu Genel Md. Raporlar serisi 531972.

CETIK, R. 1972. Vegetation of Central Anatolia and its ecology. Cento Seminar on arid and semiarid zones: 109-128.

CETIK, R. 1976. Phytosocir logical and phytoecological studies of Cedrus woodland vegetation of Çığhlkara and Bucak, Elmal. Communs Fac. Sc. Univ. Ankara. Seri C 2/20.

SAVIS, P.H. 1985-86. Flora of Turkey and Eastern Aegen Islands. vol: 1-9. Univ. Pres. Edinburgh.

EKJM, T. 1977. Sündiken dağlan (Eskişehir) ve jetasyonunun sosyolojik ve Fkolojik yönden araştırılması Doçentlik rezi.

KETENOĞLU, O. QUEZEL, P., AKMAN, Y. and AYDOĞDU, M. 1983. New syntaxa on the gypsaceus formations in the Centfal Anatolia. Ecologia mediterranea, IX (3-4): 211-221.

KILINÇ, M. 1974. Kurkkkale-Kalecik ve Elmadağ arasındaki serpantin formasyonu üzerinde ekolojik ve sosyolcjik bir araştırma. Bitki 1/4: 479-521.

Meteoroloji Bültteni 1984. Ortalama, ekstrem sıcaklık ve yağıș değerleri. T.C. Başbakanlık Devlet Meteoroloji ișleri Genel Müdürliuğü.

OCAKVERDI, H. 1983. Seydişehir (Konya) Maden bölgesinin fitososyolojik ve fitoekolojik yönden incelenmesi (Doktora tezi). 
QUEZEL, P., BARBERO, M et AKMAN, Y. 1980. Contribution a l'étude de la végétation forestiére d'Anatolie septentrionale. Phytocoenologia 8 (3/4): 365-519.

VURAL, M., EKIM, T., ILARSLAN, R. ve MALYER, H. 1985. Afyon Başkomu ‘an Tarihi Milli parkı vejetasyonu. Dağa, seri a2 (9/2) 363-387.

ZOHARY, M. 1973. Geobotanical foundation of the Middle East. vol. I-II. Gustav Fischer Verlag. Stuttgart. 